\title{
The Analysis of the Translation Quality of the Nominal Group and the Shift of the Elements of the English Nominal Group to the Indonesian Nominal Group
}

\author{
Ade Sukma Mulya $^{1 *}$, M R Nababan ${ }^{2}$, Riyadi Santoso ${ }^{3}$, Tri Wiratno ${ }^{4}$ \\ \{adesukmamulya01@gmail.com ${ }^{1}$ \} \\ Universitas Sebelas Maret, Indonesia
}

\begin{abstract}
The present research aims (1) to identify and describe the shift of the elements of the nominal groups, (2) to identify and describe the translation accuracy of the nominal group ,(3) to identify and describe the acceptability of the translation of the nominal group, (4) to identify and describe the readability of the translation of the nominal group,This descriptive qualitative research applied purposive sampling technique. There were 822 data of the nominal group. The data collection technique that was used was :(1) observation to get the sentences which contained the nominal group, (2) the questioners and interviewed with key informants to get the accurate translation of nominal group, to get the acceptable translation of the nominal group, to get the readable translation of the nominal group. The research findings show the followings. The shift of the nominal group element can function as guidance to translate the nominal English group. The total score of the translation quality was 2,86 , from the rank $1-3$, so the quality assessment of the translation of the nominal group was near perfect.
\end{abstract}

Keywords: quality, accuracy, acceptability, and readability

\section{Introduction}

The research of the assessment of quality translation of the nominal groups and the analysis of the shift of the elements of the nominal groups are very important aspects in research to do to minimize inaccurate results in translating the nominal English group. The results of previous results indicated that there was some inaccurate translation when translating nominal groups. If the inaccurate translations of the nominal groups continue to happen, such condition will affect the quality of the translation book. However, if the problem of the inaccurate translation of the nominal groups can be overcome, it will improve the quality of translation books.

The nominal group in a sentence has an important role because the nominal group can function as subject or complement. If a nominal English group is translated accurately into the Indonesian language, the process of translation almost finishes because only one element is left to translate, that is a verb or predicate.

The research about the quality translation of the nominal groups had been done by some researchers, but the results have not shown to find a solution how to translate the nominal group accurately. As such result, there must be opportunities to do the research related to the translation of the nominal groups. 
To find out the problem of the translation of a nominal group, the researchers assessed the translation quality of nominal groups as a part of a sentence, and also analyze the shift of the element of the nominal groups after they have been translated into the Indonesian language. One of the most important parts of the nominal group translation is how the shift of the element of the nominal group is formed after being translated into Indonesian nominal groups. The shift of the nominal groups can be used by a translator as guidance to translate the nominal group.

The writers took the sentences which contained the nominal groups and its translation from the textbook of the Organizational Behavior, and the nominal group of the sentences was analyzed to find the correct data. The correct data were then analyzed for the shift of the element of the nominal groups, and the nominal group translations were assessed for the quality of the translation.

The main purposes of the research were (1) to identify the shift process of the element structure of the English nominal group into the element structure of Indonesian nominal group, and (2) to assess the translation quality of the nominal group, (3) the analysis of shifts of the elements of the nominal groups from English into Indonesian language (Bahasa). To achieve the purposes of the research, the researchers learned more about the nominal groups and its shifts of the elements and how to translate the nominal group into Indonesia language accurately using the shifts of the elements of the nominal groups, and learn to assess the quality translation of the nominal group from English into Indonesian language.

The previous research that was conducted by the writers were about the quality translations of the sentences which described the marketing concept, and model of translation. The writer considered the two kinds of research are generals, so the writers continued doing another research to improve the previous research to be more focus research.

The number of the researchers who had conducted the research about a quality translation of the nominal group were [1], [2], [3], [4], and [5]. Their research focused on the assessment of translation quality of the nominal group and identification of the shifts of the element of the nominal group, but they have not discussed the function of the shift of the nominal group to produce the translation accuracy in a target language. The strength of their research could identify the quality of the nominal group translation well, but the weakness of the research, the researchers, have not analyzed the role of the shift of the nominal group related to how to produce the accurate translation of the nominal group, and the researches have not produced a model of translating nominal groups.

The research gaps between the previous research and the current research lie in the analysis of the shift of the nominal groups that can be used as a guide to translate the nominal group accurately.

\section{The Material and Methology}

To result in the accurate translation of the nominal group, a translator must understand the theory of the nominal group so that the translator can describe the elements of a nominal group. Then, from the element of the nominal group, a translator can use them as s guide to translate the nominal groups. The nominal group is a part of the systemic functional linguistics. Nominal groups are dominant parts of a sentence that acts as a subject or complement. The nominal group consists of two main elements, they are a head element, and modifying element. The head element is the thing, the element in which the semantic core of the nominal group, and modifying element. The modifying elements consist of a classifier, ephitet, enumerative, and deictic. A classifier is an element that indicates the particular 
subclass or subgroup of the entity. The epithet, the element which refers to some qualitative feature of the entity. Numerative is the element which specifies some quantitative or ordinative feature being identified. Deictic is the element which indicates whether or not some specific subset of the entity. A qualifier is a piece of additional information to the thing. The qualifier can be an adjective clause, present participle, past participle, prepositional phrase. Infinitive [6], [7], [8], [9], [10], [11].

To produce a quality translation, a translator also must understand the process of translation. The translating process will involve the equivalence, translation technique, ideology and methods of translation.

Equivalence: the core process of translating is message transfer from the source language (SL) into the target language (TT). The message should be equivalent in meaning intended in the source language. Meaning equivalence is very important aspect in translation, so the translator must focus on the meaning equivalence between SL and TT when translating a word, phrase, clause, sentence and a text of the source language into target language [12], [13], [14], [15], [16], [17], [18].

Translation Ideology Foreignization Ideology believes that ST culture has to be preserved in the translation product, the translator believes that ST culture, customs, and habits are important for the readers of the translation product. [19] quoted Venuti stated that in foreignization ideology, the translator as if"sending the reader abroad." [20] states that" a good translation product is the one which preserves the style and the taste of ST culture. To realize the foreignization ideology, the translators use translation methods of word-for-word translation, literal translation, faithful translation dan semantic translation. Those four methods enable the translator to preserve the content in the ST culture as the equivalence tends to be formal or rigid to preserve the ST culture Yang [21].

\section{Translation Methods}

By the time a translator facing a text to be translated, the first thing to do is deciding what method she is going to apply. [22] as quoted in Nababan stated" basically translation methods will be decided before a translator starts her translation process." [23] states that translation methods are how a translation process is carried out is related to the purpose of the translation. Translation methods is a global choice influencing the whole text. Translation methods are influenced by the translation ideology believed by the translator. A translator following foreignization ideology will choose a translation method which preserves ST culture, on the other hand, a translator with domestication belief will choose a translation method enabling her to change the ST culture into the TT culture.

Table 1. The nstrument of the assessment of the accurate translation [23]

\begin{tabular}{ccl}
\hline Translation category & Score & \multicolumn{1}{c}{ Qualitative parameter } \\
\hline Accuracy & 3 & $\begin{array}{l}\text { The meaning of word, technical terminology, phrase, clause, } \\
\text { sentence or text were translated accurately into target } \\
\text { language, and there is no meaning distortion, }\end{array}$ \\
\hline Less-accuracy & 2 & $\begin{array}{l}\text { Most of the meaning of word, technical terminology, phrase, } \\
\text { clause, sentence or text have been translated accurately into } \\
\text { target language, and there is a meaning distortion, }\end{array}$ \\
\hline Not accuracy & 1 & $\begin{array}{l}\text { The meaning of word, technical terminology, phrase, clause, } \\
\text { sentence or text were translated unaccurately into target } \\
\text { language. }\end{array}$ \\
\hline
\end{tabular}


This research is a qualitative descriptive using the single-embedded case study because the focus of the research has been determined in advance. The research is descriptive because the research was done by collecting, grouping, analyzing and interpreting the data research. The data were 822 data of the nominal groups taken from the texts book "Organizational Behavior" written by [24]. The technique of collecting data used the purposive samplings. The data resource was from the texts book of Organizational Behavior and its translation, and from focus group discussion with the information related with the translation quality. The technique of collecting data was done by document analysis, and focus group discussion (FGD). The procedure of the data analysis naturally follow the flow of domain, taxonomy, componential analysis, and cultural theme, and the research analysis adapted the model of the data analysis of Spradley (1977) quoted by Santosa [25].

\section{The Results and Discussion}

\subsection{The Analysis of the Shift of the English Nominal Group to Indonesian Nominal Group}

From the results of the analysis about how a shift is formed when translating the English nominal groups into the Indonesian Nominal Group. The shifts are below

3.1.1. The element of the nominal group : The Thing becomes Thing Deictic or Thing (single noun) becuase the article the, a , an is sometimes not translated . or Thing Deictic

\begin{tabular}{clll}
\hline $\begin{array}{c}\text { English Nominal } \\
\text { Group }\end{array}$ & $\begin{array}{l}\text { Element of the } \\
\text { English of the } \\
\text { nominal group }\end{array}$ & $\begin{array}{l}\text { Element of } \\
\text { Indonesian nominal } \\
\text { group }\end{array}$ & Translation \\
\hline our definition & Deictic Thing & Thing Deictic & Definisi tersebut \\
\hline $\begin{array}{c}\text { English Nominal } \\
\text { Group }\end{array}$ & $\begin{array}{l}\text { Element of the } \\
\text { English of the } \\
\text { nominal group }\end{array}$ & $\begin{array}{l}\text { Element of } \\
\text { Indonesian } \\
\text { nominal group }\end{array}$ & Translation \\
\hline The workplace & Deictic & Thing & Tempat kerja \\
\hline $\begin{array}{c}\text { English Nominal } \\
\text { Group }\end{array}$ & $\begin{array}{l}\text { Element of the } \\
\text { English of the } \\
\text { nominal group }\end{array}$ & $\begin{array}{l}\text { Element of } \\
\text { Indonesian nominal } \\
\text { group }\end{array}$ & Translation \\
\hline a company & Deictic Thing & Thing Deictic & Sebuah perusahaan \\
\hline
\end{tabular}

3.1.2. The shift of the elements of the English Nominal Group to The Indonesian nominal Group: Ephitet Thing becomes Thing Ephitet or Thing +Qualifier (adjective clause)

\begin{tabular}{clll}
\hline $\begin{array}{c}\text { English Nominal } \\
\text { Group }\end{array}$ & $\begin{array}{l}\text { Element of the } \\
\text { English of the } \\
\text { nominal group }\end{array}$ & $\begin{array}{l}\text { Element of } \\
\text { Indonesian nominal } \\
\text { group }\end{array}$ & Translation \\
\hline $\begin{array}{c}\text { productive } \\
\text { workers. }\end{array}$ & Ephitet Thing & $\begin{array}{l}\text { Thing +Q(adjective } \\
\text { clause) }\end{array}$ & $\begin{array}{c}\text { Pekerja yang } \\
\text { produktif }\end{array}$ \\
\hline
\end{tabular}


3.1.3. The shift of the elements of the English Nominal Group to The Indonesian nominal Group: Deictic Ephitet Thing (DET) becomes Thing Ephitet Deitic or Thing Ephitet

\begin{tabular}{llll}
\hline $\begin{array}{l}\text { English Nominal } \\
\text { Group }\end{array}$ & $\begin{array}{l}\text { Element of the } \\
\text { English of the } \\
\text { nominal group }\end{array}$ & $\begin{array}{l}\text { Element of } \\
\text { Indonesian nominal } \\
\text { group }\end{array}$ & Translation \\
\hline $\begin{array}{l}\text { The selection } \\
\text { process }\end{array}$ & $\begin{array}{l}\text { Deictic Ephitet } \\
\text { Thing }\end{array}$ & $\begin{array}{l}\text { Thing Ephitet or } \\
\text { Thing Ephitet } \\
\text { Deictic }\end{array}$ & $\begin{array}{l}\text { Proses Seleksi atau } \\
\text { proses seleksi } \\
\text { tersebut }\end{array}$ \\
\hline
\end{tabular}

3.1.4. The shift of the elements of the English Nominal Group to The Indonesian nominal Group : Classifier Thing (CT) becomes Thing Classifier TC

\begin{tabular}{clll}
\hline $\begin{array}{c}\text { English Nominal } \\
\text { Group }\end{array}$ & $\begin{array}{l}\text { Element of the } \\
\text { English of the } \\
\text { nominal group }\end{array}$ & $\begin{array}{l}\text { Element of } \\
\text { Indonesian } \\
\text { nominal group }\end{array}$ & Translation \\
\hline Theoretical model & Classifier Thing & Thing Classifier & Model teoretis \\
\hline
\end{tabular}

3.1.5. The shift of the elements of the English Nominal Group to The Indonesian nominal Group: DeicticThing $+Q$ (adjective clause) becomes Thing Deictic +qualifier (adjective clause) or $\mathbf{T}+\mathbf{Q}$ (adjective Clause)

\begin{tabular}{cllc}
\hline $\begin{array}{c}\text { English Nominal } \\
\text { Group }\end{array}$ & $\begin{array}{l}\text { Element of the } \\
\text { English of the } \\
\text { nominal group }\end{array}$ & $\begin{array}{l}\text { Element of } \\
\text { Indonesian } \\
\text { nominal group }\end{array}$ & Translation \\
\hline $\begin{array}{c}\text { the events or } \\
\text { object that } \\
\text { started the } \\
\text { feelings }\end{array}$ & $\begin{array}{l}\text { DT+Q (adjective } \\
\text { clause }\end{array}$ & $\begin{array}{l}\text { TD+Q(adjective } \\
\text { clause) }\end{array}$ & $\begin{array}{c}\text { peristiwa atau obyek yang } \\
\text { memulai perasaan itu }\end{array}$ \\
\hline
\end{tabular}

3.1.6. The shift of the elements of the English Nominal Group to The Indonesian nominal Group: Deictic Thing + Q ( prepositional Phrase becomes Thing Deictic + Q (prepositional phrase)

\begin{tabular}{|c|c|c|c|}
\hline $\begin{array}{l}\text { English Nominal } \\
\text { Group }\end{array}$ & $\begin{array}{l}\text { Element of the } \\
\text { English of the } \\
\text { nominal group }\end{array}$ & $\begin{array}{l}\text { Element of } \\
\text { Indonesian } \\
\text { nominal group }\end{array}$ & Translation \\
\hline $\begin{array}{c}\text { Another study of } \\
8000 \text { firms in } 20 \\
\text { countries ( } \\
\text { OB/Bab1/H45/P2). }\end{array}$ & $\begin{array}{l}\text { Deictic Thing } \\
+Q \text { (prepositionel } \\
\text { phrase }\end{array}$ & $\begin{array}{l}\text { Thing Deictic } \\
+\mathrm{Q} \text { (prepositional } \\
\text { phrase }\end{array}$ & $\begin{array}{c}\text { Kajian lainnya } \\
\text { pada } 8000 \\
\text { perusahaan di } 20 \\
\text { negara } \\
\text { (Ob/Bab1/Hal } \\
\text { 8/P.2/B 11). }\end{array}$ \\
\hline
\end{tabular}


3.1.7. The shift of the elements of the English Nominal Group to The Indonesian nominal Group: Deictic Thing $+Q$ (past participle) becomes Thing $+Q$ (djective Clause

\begin{tabular}{cllc}
\hline English Nominal Group & $\begin{array}{l}\text { Element of the } \\
\text { English of the } \\
\text { nominal group }\end{array}$ & $\begin{array}{l}\text { Element of } \\
\text { Indonesian } \\
\text { nominal group }\end{array}$ & Translation \\
\hline $\begin{array}{c}\text { the purpose of applying } \\
\text { such knowledge toward }\end{array}$ & $\begin{array}{l}\text { Deictic Thing } \\
\text { improving an organization's } \\
\text { effectiveness( }\end{array}$ & $\begin{array}{l}\text { Thing } \\
+\mathrm{Q} \text { (prepositioa } \\
\text { 1 phrase }\end{array}$ & $\begin{array}{c}\text { tujuan } \\
\text { penerapan }\end{array}$ \\
$\begin{array}{c}\text { OB/Bab1/H42/P4).OB/Bab1 } \\
\text { /H42/P4). }\end{array}$ & & $\begin{array}{c}\text { pengetahuan demi } \\
\text { peningkatan } \\
\text { efektivitas } \\
\text { organisasi }\end{array}$ \\
\hline
\end{tabular}

3.1.8. The shift of the elements of the English Nominal Group to The Indonesian nominal Group: Deictic Ephitet Thing +Q(infinitive) becomes Thing Ephitet +Q(infinitive)

\begin{tabular}{llll}
\hline $\begin{array}{l}\text { English Nominal } \\
\text { Group }\end{array}$ & $\begin{array}{l}\text { Element of the } \\
\text { English of the } \\
\text { nominal group }\end{array}$ & $\begin{array}{l}\text { Element of } \\
\text { Indonesian nominal } \\
\text { group }\end{array}$ & Translation \\
\hline $\begin{array}{l}\text { his ability to } \\
\text { experience } \\
\text { emotion }\end{array}$ & $\begin{array}{l}\text { Deictic Thing } \\
+Q(i n f i n i t i v e)\end{array}$ & $\begin{array}{l}\text { Thing Ephitet } \\
+Q(\text { infinitive) }\end{array}$ & $\begin{array}{l}\text { Kemampuan untuk } \\
\text { merasakan emosi }\end{array}$ \\
\hline
\end{tabular}

3.1.9. The shift of the elements of the English Nominal Group to The Indonesian nominal Group: Ephitet Classifier Thing becomes Thing Classifier +Q(adjective clause)

\begin{tabular}{|c|c|c|c|}
\hline $\begin{array}{l}\text { English Nominal } \\
\text { Group }\end{array}$ & $\begin{array}{l}\text { Element of the } \\
\text { English of the } \\
\text { nominal group }\end{array}$ & $\begin{array}{l}\text { Element of } \\
\text { Indonesian nominal } \\
\text { group }\end{array}$ & Translation \\
\hline low morale group & $\begin{array}{l}\text { Ephitet Classifier } \\
\text { Thing }\end{array}$ & $\begin{array}{l}\text { Thing Classifier } \\
+\mathrm{Q} \text { (adjective } \\
\text { clause) }\end{array}$ & $\begin{array}{l}\text { Kelompok moral } \\
\text { yang rendah }\end{array}$ \\
\hline
\end{tabular}


3.1.10. The shift of the elements of the English Nominal Group to The Indonesian nominal Group: Ephitet Ephitet Thing +Q(prepositional phrase) becomes Thing Ephitet $+Q($ adjective clause)

\begin{tabular}{llll}
\hline $\begin{array}{l}\text { English Nominal } \\
\text { Group }\end{array}$ & $\begin{array}{l}\text { Element of the } \\
\text { English of the } \\
\text { nominal group }\end{array}$ & $\begin{array}{l}\text { Element of } \\
\text { Indonesian } \\
\text { nominal group }\end{array}$ & \multicolumn{1}{c}{ Translation } \\
\hline $\begin{array}{l}\text { stressful daily events } \\
\text { at work ( a nasty } \\
\text { email , an }\end{array}$ & $\begin{array}{l}\text { Ephitet Ephitet } \\
\text { Thing+Q(prepositio } \\
\text { nal phrase) } \\
\text { the loss of a big sale, } \\
\begin{array}{l}\text { a reprimand from } \\
\text { the boss }\end{array}\end{array}$ & $\begin{array}{l}\text { Thing } \\
\text { Ephitet+Q(adje } \\
\text { ctive clause) }\end{array}$ & $\begin{array}{l}\text { peristiwa harian yang } \\
\text { memberi tekanan di } \\
\text { tempat kerja ( e-mail } \\
\text { menjijikan, tenggat waktu } \\
\text { yang semakin dekat, } \\
\text { kehilangan penjualan yang } \\
\text { besar, teguran dari atasan) }\end{array}$ \\
\hline
\end{tabular}

\subsection{The Analysis Of The Accurate Translations Of Nominal Group}

There were 822 data of the nominal groups which were assessed for the categories of the accuracy, less accuracy and not accuracy.

Table 2. The accuracy of the nominal group translation:

\begin{tabular}{lccc}
\hline $\begin{array}{l}\text { The accuracy of the } \\
\text { nominal group } \\
\text { translation }\end{array}$ & The number & The precentage & The average \\
\hline $\begin{array}{l}\text { a. Data of the accurate } \\
\text { translation }\end{array}$ & 769 & $93.55 \%$ & $(769 \times 3)+(48 \times 2)+(5 \times 1):$ \\
$\begin{array}{l}\text { b. Data of less accurate } \\
\text { translation }\end{array}$ & 48 & $5.83 \%$ & $822=2.93$ \\
$\begin{array}{l}\text { c. Data of not accurate } \\
\text { translation } \\
\quad \text { Total }\end{array}$ & 5 & $0,61 \%$ & 2.93 (Scale 1-3) \\
\hline
\end{tabular}

The example: the translation of nominal group with the category of accurate translation. Source language: Organizations that don't help their people achieve work-life balance will find it increasingly difficult to attract and retain the most capable and motivated employees (OB/Bab1/H54/P2). Target Language : Organisasi yang tidak membantu pekerjanya mencapai keseimbangan kerja -hidup akan menemukan kesulitan untuk menarik dan mempertahankan pekerja yang paling berkemampuan dan termonivasi (Ob/Bab1/Hal 15/P.3/B 1). The translation of the nominal group is accurate because all words in the nominal English group have been translated accurately.

The example 2: the translation of nominal group with the category of less accurate translation. Source language: The shared characteristic of their jobs is substantial interaction with an organization's customer (OB/Bab1/H52/P6). Target language: Karakteristik bersama 
dari pekerjaan Mereka adalah interaksi substansial dengan pelanggan organisasi (Ob/Bab1/Hal 14/P.2/B 3). Explanation: There is a distortion of meaning: share was translated bersama.

Example 3: The translation of the nominal group which was not accurate. Source language: A study that looked at how cheerleading instructors spent their breaks from teaching found those who used the time to rest and relax were more effective after their breaks (OB/Bab 4/ H 134/P3/B 13). Target language: Sebuah studi yang mempelajari bagaimana instruktur pemandu menggunakan jam mengajarnya untuk istirahat mendapati bahwa mereka yang menggunakan waktunya untuk istirahat dan rilek lebih efektif sesudah istirahat ( Bab4/69/P1/B3). Explanation : the translation of the nominal group is not accurate, becuase there is a distortion of meanings.

Table 3. The results of the Analysis of the Acceptability

\begin{tabular}{lccc}
\hline $\begin{array}{l}\text { The cataegory : the } \\
\text { acceptability of the } \\
\text { translation of nominal } \\
\text { group }\end{array}$ & The number & Percentage & The Average \\
\hline $\begin{array}{l}\text { Data of acceptability } \\
\begin{array}{l}\text { Data of less } \\
\text { acceptability }\end{array}\end{array}$ & 790 & 96.11 & $(790 \times 3)+(32 \times 2)+$ \\
$\begin{array}{l}\text { Data of } \\
\text { unaccepatability }\end{array}$ & 32 & 3.89 & $(0 \times 1): 822=2.97$ \\
\hline Total score & 0 & 0 & 2.96 \\
\hline
\end{tabular}

The example of the transltion of the nominal group which categories the acceptable translations of the nominal group. Source language : Instructors who did chores during their breaks were only about as effective after their break as they were before (OB/Bab $4 / \mathrm{H}$ 134/P3/B akhir). Target language : Instruktur yang tetap melatih saat jam istirahat hanya seefektif sebelumnya sesudah istirahatnya ( Bab4/69/P1/B5). Explanation: the translation is natural.

The example of nominal group translation which catagorise less acceptability. Source langauge : For people who are poor or who live in poor countries, pay does correlate with job satisfaction and overall happiness (OB/ Bab 3/H109/P.1). Target language: Untuk orangorang yang miskin atau hidup di negara miskin, gaji benar-benar berkorelasi dengan kepuasaan kerja dan kebahagian keseluruhan (OB/ Bab3/H.51/P.3/b.2). Explanation: Geenerally, the translations are natural; but there is a slight problem with the use of the expression. The results of the Analysis of the translation quality of the nominal group with the readability category. 


\begin{tabular}{lccc}
\hline The category : Readability & The number & Presentage & The average \\
\hline $\begin{array}{l}\text { a. Data of high level of the } \\
\text { readability }\end{array}$ & 800 & 97.08 & \\
$\begin{array}{l}\text { b. Data of moderate level of the } \\
\text { readability }\end{array}$ & 22 & 2.67 & $\begin{array}{c}(800 X 3)+(22 \times 2)+ \\
(2 X 1): 822=2.96\end{array}$ \\
$\begin{array}{l}\text { c. Data of the low level of the } \\
\text { readability }\end{array}$ & None & None & \\
\hline \multicolumn{1}{c}{ Total } & 822 & 100 & 2.96 \\
\hline
\end{tabular}

The example of the translation of the nominal group which categories the acceptable translations of the nominal group. Source language: Instructors who did chores during their breaks were only about as effective after their break as they were before (OB/Bab $4 / \mathrm{H}$ 134/P3/B akhir). Target language: Instruktur yang tetap melatih saat jam istirahat hanya seefektif sebelumnya sesudah istirahatnya ( Bab4/69/P1/B5). Explanation: the translation is natural.

The example of nominal group translation which categorizes less acceptability. Source language: For people who are poor or who live in poor countries, pay does correlate with job satisfaction and overall happiness (OB/ Bab 3/H109/P.1). Target language: Untuk orang-orang yang miskin atau hidup di negara miskin, gaji benar-benar berkorelasi dengan kepuasaan kerja dan kebahagian keseluruhan (OB/ Bab3/H.51/P.3/b.2). Explanation: Generally, the translations are natural; but there is a slight problem with the use of the expressio. The results of the Analysis of the translation quality of the nominal group with the readability category.

Source language: If everyone who faces a similar situation responds in the same way, we can say the behavior shows consensus (OB/Bab 6/H 186/P 5/B 1). Target language: Jika setiap orang menghadapi situasi yang sama memberikan respons yang sama, kita dapat mengatakan perilaku itu menunjukkan consensus (OB/Bab 6/H 105/ P 5/baris 1).

The shift of the elements of the nominal groups is a very important aspect in the process of translating English to the Indonesian language. A translator must understand the shift before doing a translation to produce a good and complete translation in the target language. The process of translating nominal English groups begin with (1) take the nominal groups from a sentence. (2) classify each element of the nominal group, (3) organize again the elements of the nominal group in the Indonesian language according to its structure, (4) the process of translation.

The researchers used the instruments [23] for assessing the translation quality of the nominal groups. The quality translation includes the accuracy, the acceptability, and the readability. The assessment of Translation quality of the nominal groups are the accurate translation, and the acceptable translation and the readable translation. From the assessment for the accuracy, from 822 data, there were 769 data or $93.55 \%$ of the nominal groups had been translated accurately. The meaning of words in nominal groups of source language was translated accurately to the target language; there is absolutely no distortion of meaning, 48 data or $5.83 \%$ of words in the nominal groups of source language was translated less accurately to the target language; because there was a distortion of meaning or double meaning translation, or there was a meaning that was omitted and Only 5 data or $0,61 \%$ of the meaning of words in the nominal groups of source language were not translated accurately to the target language.

The assessment of acceptable translation, from 822 data, there were 790 or $96,11 \%$ data of the nominal group translation were acceptable. The translations were natural; the translation 
of the nominal groups was commonly used and familiar with readers, and 32 or 3,89\% of the nominal group translations were less acceptable. The translations were not natural or felt like a translation work.

There were 800 or $97,08 \%$ data of the nominal group translation had a high level of the readability. The nominal groups translated could be easily understood by readers, 22 or 2,67 $\%$ of the nominal group translations had a moderate level of the readability. Generally, the translation can be understood by readers, but there was a part of the nominal group must be read more than once.

\section{Conclusion}

The research has been done successfully to analyze the shift of the nominal groups either the nominal groups of the source language and the nominal groups of the target language. The results of the shift of the nominal group can be developed to be a model for guiding to translate the nominal group, and the model can help a translator to translate the nominal English groups into Indonesian language (Bahasa) accurately. About the assessment of the quality translations of the nominal group, the results showed that there were some less accurate translation, less acceptable translations and the moderate level of translation readability. These findings showed that there is a problem with the translation of the nominal groups. By the findings of the research, there will be a potential area of further research. The potential area of further research is a model of translation of the nominal group

\section{References}

[1] F. N. Aini, Analisis Terjemahan Kelompok Nomina dalam Novel Twilight Karya Stephene Mayer. Solo: Perpustakaan Pusat UNS., 2016.

[2] I. N. Hidayah, . Dampak pergeseran kelompok nomina dalam dua pidato kenegaraan Presiden Amerika Serikat Barac Obama dan terjemahannya terhadap kualitas terjemahan. Solo: Perpustakaan Pusat UNS., 2013.

[3] D. R. Purwandingsih, Analisis teknik dan kualitas terjemahan unsur pre-modifier dalam kelompok nomina dalam Novel The Da Vinci Code. Solo: Perpustakaan Pusat UNS., 2010.

[4] R. Wijayava, Analisis nomina abstract derivatif dalam Novel Princess Diaries dan terjemahaanya Sang Putri Berpesta. Solo: Perpustakaan Pusat UNS, 2008.

[5] S. Suparno, Analisis penerjemahan frasa nomina bahasa Inggris pada buku"The Essence Of Services Marketing” dan Padanannya Dalam Bahasa Indonesia Pada Buku Pemasaran Jasa. Solo: Perpustakaan Pusat UNS, 2005.

[6] H. M.A.K., Halliday's introduction to functional grammar. New York: Routledge, 2014.

[7] R. Santosa, No TitleMetodologi penelitian kualitatif. Solo: UNS Press, 2017.

[8] R. Wiratno, T. \& Santosa, Pengantar linguistik umum. Jakarta: Pengantar linguistik umum, 2011.

[9] I. G. M. Sutjaja, Semantic Interpretation of the nominal group structure in bahasa Indonesia. Sidney: University of Sydney, 1998.

[10] M. Li., "A systemic functional study of the English nominal group with a number of," Int. J. English Linguist., vol. 4, no. 5.

[11] M. Li., "A systemic functional study of head identification of the English nominal group, theory and practice in Language Studies," Int. J. English Linguist., vol. 5, no. 1, pp. 79-84, 2015.

[12] M. Baker, In other words: A coursebook on translation. New York: Routledge, 1992.

[13] S. \& M. Basnet, Translation studies. New York: Routledge, 1991.

[14] A. Cruse, Meaning in language, an intoduction to semantics and pragmatics. New York: Oxford University Press Inc., 2004.

[15] E. \& A. Gutt, Translation and relevance. New York: Routledge, 2010.

[16] M. Hatim, B \& Jeremy, Translation, an advance resource Book. New York: Routledge, 2004. 
[17] K. Malmkjaer, Linguistics and language of translation. Endinburgh: Endinburgh University Press., 2005.

[18] Ran.S., "Philosophical interpretation on E.A Nida's definition of translation," vol. 5, no. 10, 2009.

[19] J. Munday, Introducing translation studies. New York: Routledge, 2001.

[20] R. Nababan, Teori terjemahan bahasa. Yogyakarta: Pustaka Pelajar, 2003.

[21] W. Yang, "Brief study on domestication and foreignization in translation," J. Lang. Teach. Res., vol. 1, pp. 77-80, 2010.

[22] M. \& Albir, Translation techniques revisited: a dynamic and functionist approach, Meta, XLVII. 4.

[23] R. N. \& S. Nababan, "Pengembangan Model Penilaian Kualitas Terjemahan," Kaji. Linguist. dan Sastra, vol. 24, no. 1, pp. 39-57.

[24] S. \& T. A. J. Robbin, Oragnizational behavior. England: Pearson, 2015.

[25] R. Santosa, Semiotika sosial : pandangan terhadap bahasa. Surabaya: Pustaka Eurika \& JP. Press, 2003. 